\title{
(8)
}

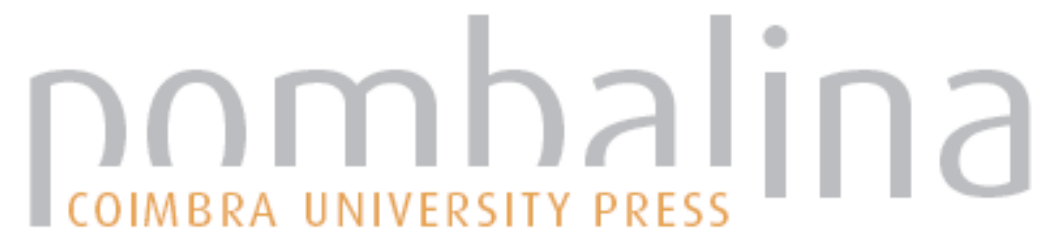

\section{Hydrodynamic modelling for Mondego estuary water quality management}
Autor(es):
Duarte, António Sampaio; Pinho, José; Pardal, Miguel Ângelo; Neto, João Magalhães; Vieira, José; Santos, Fernando Seabra

Publicado por: Imprensa da Universidade de Coimbra

URL

persistente:

URI:http://hdl.handle.net/10316.2/32647

DOI:

DOI:http://dx.doi.org/10.14195/978-989-26-0336-0_3

Accessed : $\quad$ 26-Apr-2023 09:37:10

A navegação consulta e descarregamento dos títulos inseridos nas Bibliotecas Digitais UC Digitalis, UC Pombalina e UC Impactum, pressupõem a aceitação plena e sem reservas dos Termos e Condições de Uso destas Bibliotecas Digitais, disponíveis em https://digitalis.uc.pt/pt-pt/termos.

Conforme exposto nos referidos Termos e Condições de Uso, o descarregamento de títulos de acesso restrito requer uma licença válida de autorização devendo o utilizador aceder ao(s) documento(s) a partir de um endereço de IP da instituição detentora da supramencionada licença.

Ao utilizador é apenas permitido o descarregamento para uso pessoal, pelo que o emprego do(s) título(s) descarregado(s) para outro fim, designadamente comercial, carece de autorização do respetivo autor ou editor da obra.

Na medida em que todas as obras da UC Digitalis se encontram protegidas pelo Código do Direito de Autor e Direitos Conexos e demais legislação aplicável, toda a cópia, parcial ou total, deste documento, nos casos em que é legalmente admitida, deverá conter ou fazer-se acompanhar por este aviso.

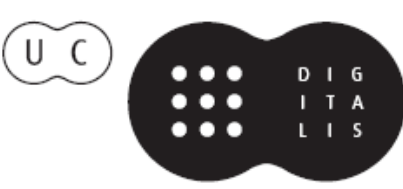


MIGUEL ÂNGELO PARDAL JOÄO CARLOS MARQUES MANUEL AUGUSTO GRAÇA Scientific Editors

\section{Aquatic Ecology of the Mondego River Basin Global Importance of Local Experience}




\author{
MIGUEL ÂNGELO PARDAL \\ JOẢO CARLOS MARQUES \\ MANUEL AUGUSTO GRAÇA \\ Scientific Editors
}

\title{
Aquatic Ecology of the Mondego River Basin Global Importance of Local Experience
}




COORDENAÇÃO EDITORIAL
Imprensa da Universidade de Coimbra
CONCEPÇÃO GRAFICA
António Barros
INFOGRAFIA
António Resende
Estimulus [design] • Coimbra
EXECUÇÃO GRAFICA
GRAFIASA
ILUSTRAÇÃO DA CAPA
P. P. Cunha e ]. Dinis
ISBN
972-8704-04-6
DEPOSITO LEGAL
I75038/02

(C) JANEIRO 2002, IMPRENSA DA UnIVERSIDADE DE COIMBRA

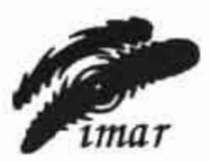

CPIMAR

imar

OBRA PUBLICADA COM O PATROCINIO DE:

IMAR - INSTITUTO DO MAR

IPIMAR - INSTITUTO DE INVESTIGAÇĀO DAS PESCAS E DO MAR 

ANTÓNIO SAMPAIO DUARTE '

JOSE PINHO ${ }^{\prime}$

Miguel ÂNGelo PARDAL ${ }^{2}$

joảo MagalHäes Neto ${ }^{2}$

JOSE VIEIRA '

FERNANDO SEABRA SANTOS ${ }^{3}$

\section{HYDRODYNAMIC MODELLING FOR MONDEGO ESTUARY WATER QUALITY MANAGEMENT}

\section{Abstract}

The south arm of Mondego estuary, located in the central western Atlantic coast of Portugal, is almost silted up in the upstream area. So, tides, wind and the tributary river Pranto discharges mostly drive the water circulation in this system. Annual freshwater inflow, regulated by precipitation and by sluice management practices, has a significant impact on flow velocity, salinity, N:P ratios and light extinction coefficients, which control biomass growth and loss processes. Eutrophication has been taking place in this ecosystem during last twelve years. where macroalgae reach a luxuriant development covering a significant area of the intertidal muddy flat.

A sampling program was carried out from June 1993 to January 1997. Available data on River Pranto flow discharges, salinity profiles, precipitation and nutrients loading into the south arm were used in order to get a better understanding of the ongoing changes.

Since hydrodynamics strongly affects the occurrence of macroalgal blooms, residence time can be a key parameter to characterise this influence. Integral formulations are typically based on assumptions of steady state and well-mixed systems and thus cannot take into account the space and time variability of estuarine residence times, due to river discharge flow, tidal coefficients, discharge(s) location and time of release during the tidal cycle.

This work presents the hydrodynamic modelling (ID and 2D-H) of this system in order to estimate some kinetic variables and the residence times variability to assess the main factors that control opportunistic macroalgal blooms, contributing to better environmental management strategres selection.

11) Departamento de Engenharia Cmil, Universidade do Minho, 4710-057 Braga , Portugal

6) IMAR - Instituto do Mar, Centro Intendisciplinar de Coimbra a/c Departamento de Zoologia, Universıdade de Coimbra, 3004-517 Combra, Portugal

o IMAR - Instituto do Mar, Centro Interdisciplinar de Coimbra a/c Departamento de Engenharia Civil, Campus 2. Universidade de Coimbra. 3030-290 Coimbra, Portugal 


\section{Introduction}

The physical and chemical dynamics and the ecology of shallow estuarine areas are strongly influenced by the freshwater runoff and the adjacent open sea. The freshwater input influences estuarine hydrology by creating salinity gradients and stratification and assures large transport of silt, organic material and inorganic nutrients to the estuaries. The open marine areas determine large scale physical and chemical forcing on the estuarine ecosystem, due to tide and wind generating water exchange (Berner and Berner 1996). Due to all this characteristics, inside the estuarine system efficient water column mixing and frequent re-suspension events ensure fast vertical transport of organic and inorganic matter (Pardal 1998) integrating the pelagic and benthic food webs and the biogeochemical processes (Lillebø 2000).

In the South Arm of the Mondego estuary eutrophication has increased due to massive nutrient loading from urbanised areas and diffusive runoff from intensively agricultural areas. This increased nutrient loading has severe consequences for the ecology of the system, due to changes in plant composition (Pardal 1998. Flindt et al. 1999), which consequently affects heterotrophic organisms, specialised in living on this production (Pardal 1998, Pardal et al. 2000, Lillebø et al. 1999). As a consequence of nutrient ennchment, opportunistic macroalgae growth was strongly stimulated allowing the occurrence of macroalgae blooms and the extinction of seagrass in more shallow areas. This situation may result in anoxic system collapse, with the development of hydrogen-sulphide conditions, lethal to rooted macrophytes such as Zostera noltii. The consequence is a structural change of the ecosystem, from a grazing controlled system to a detritus/mineralisation system (Pardal 1998), where the turnover of oxygen and nutrients is much more dynamic (Lavery and McComb 1991), and macroalgae play an important role in the nutrient pathways of the ecosystem.

Thus, due to the importance of their impacts in the ecosystem, it becomes crucial to obtain information on the mechanisms that regulate the abundance of opportunistic macroalgae. Advective transport may be the most important process that controls the spatial and temporal distribution of macroalgae. Depending on the tidal amplitude. depth, cohesiveness of plant material, current velocity, wind and wave-induced vertical turbulence, plants growing in shallow areas are suspended in the water column and transported out and eventually settled in deeper areas (Sfriso et al. 1992). In this system, available data analysis allows to conclude that the occurrence of green macroalgal blooms is strongly dependent on the hydrodynamic conditions, 30 precipitation and salinity gradients (Martins et al. 2001).

A wide range of mathematical models has been developed and applied to predict water quality changes in surface waters, being a useful tool for systems eutrophication vulnerability assessment (Vieira et al. 1998). Residence times estimation, allowed by mathematical modelling, can provide essential information about estuarine hydrodynamic behaviour, considering different scenarios, in order to select better water quality management practices (Duarte et al. 200I).

The aim of this study is to assess the role of estuarine hydrodynamics on the macroalgae biomass control, because the quantitative aspects of this phenomenon are 
not well known. Hydrodynamic models (ID and 2D-H) of Mondego estuary south arm were implemented in order to estimate residence times, current velocity and salinity distribution at different simulated scenarios, considering average tidal conditions. The conclusions of an early study about the macroalgae growth behaviour and the monitoring program results analysis are also presented. In further research works. useful tools for an estuarine integrated management will be developed in order to support the decision making process (Vieira and Lijklema 1989).

The present work was based on previous published results, namely Pardal (1998) and Duarte et al (200I).

\section{Study area}

The Mondego river basin is located in the central region of Portugal. The drainage area is $6,670 \mathrm{~km}^{7}$ and the annual mean rainfall is between 1,000 and 1,200 $\mathrm{mm}$. This estuary $\left(40^{\circ} 08^{\prime} \mathrm{N} 8^{\circ} 50^{\prime} \mathrm{W}\right)$ has a considerable regional importance due to the Figueira da Foz mercantile harbour, but is under severe environmental stress, namely an ongoing eutrophication process, due to human activities: industries. aquaculture farms and nutrients discharge from agricultural lands of low river Mondego valley (Fig. I).

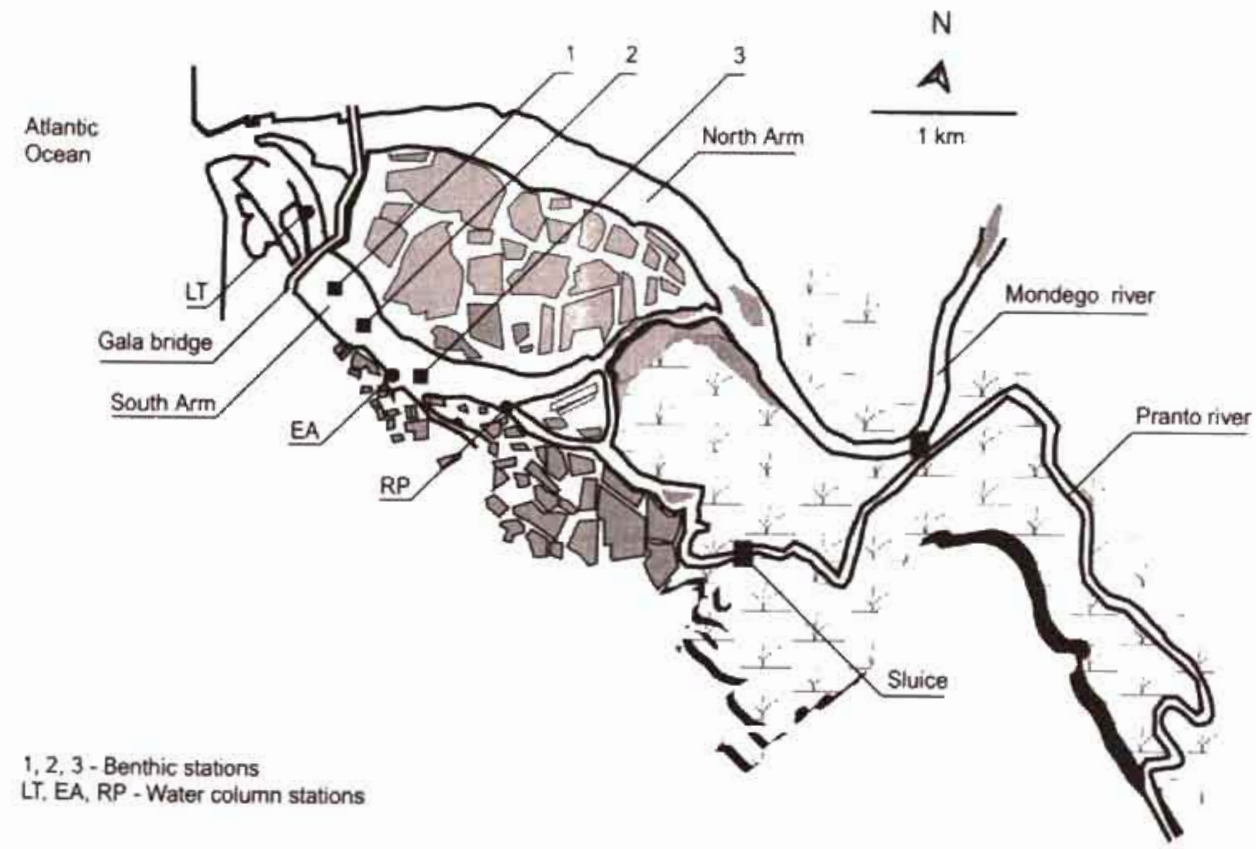

Figure I. River Mondego estuary and sampling stations location 
This estuarine system is divided into two arms (north and south) with very different hydrological characteristics, separated by the Murraceira Island. The north arm is deeper and receives the majority of freshwater input (from Mondego river), while the south arm of this estuary is shallower ( 2 to $4 \mathrm{~m}$ deep, during high tide) and is almost silted up in the upstream area (Fig.2). Consequently, the south arm estuary water circulation is mainly due to tides, wind and the usually small freshwater input of Pranto River, a tributary artificially controlled by a sluice, located about $6 \mathrm{~km}$ from the mouth.

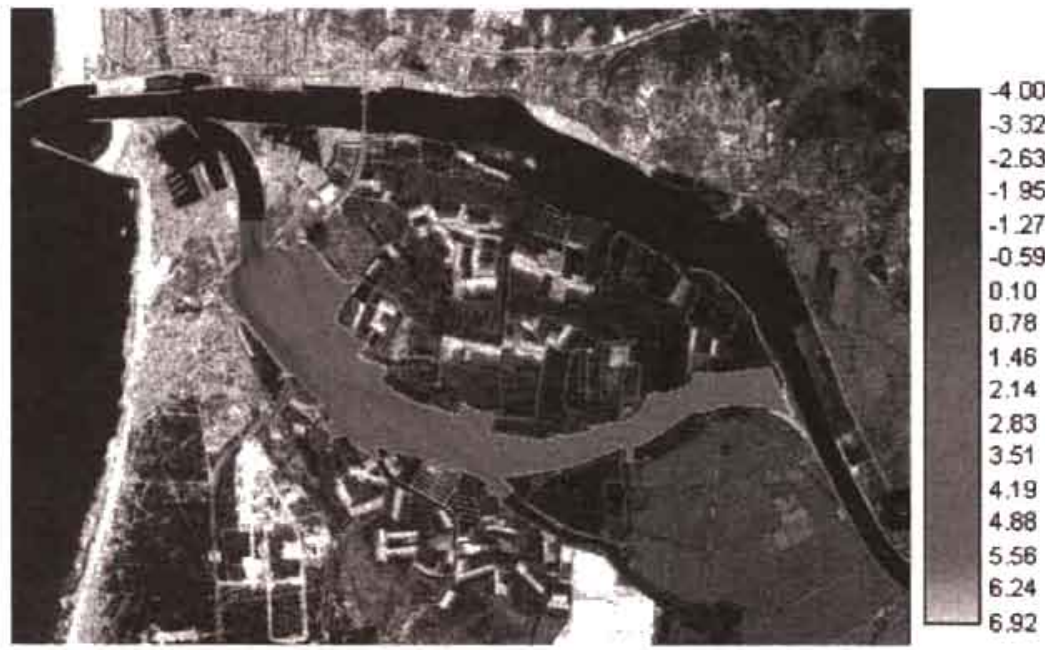

Figure 2. Bathymetry of the Mondego estuary south arm

\section{Methods}

\section{Monitoring program}

Most of the estuarine processes (physical, chemical and biological) are related to salinity, because its variation is one of the major characteristics of an estuarine system. For the water sampling location and benthic stations (Fig. I), an indication of the variability in the local salinity regime over a tidal period (for little and high river discharges) can facilitate future interpretation of the data.

A sampling program was carried out from June 1993 to January 1997 at three benthic stations (1.2 and 3) during low water tide, and, from June 1993 to June 1994.

32 at three other sites: river Pranto sluice, Armazéns channel mouth and Gala bridge for water column monitoring. In this period, the river Pranto freshwater input was estimated ( 68 times during sluice openings), measuring current velocities immediately after the sluice. The current velocity was also measured immediately after the Gala Bridge, at different depths and along cross section. The field data were used to define the boundary conditions of the hydrodynamic model.

The choice of benthic stations was related with the observation of an eutrophication gradient in the south arm of the estuary, involving the replacement of eelgrass, Zostera noltii by green algae such as Enteromorpha spp. and Ulvo spp.. There is 
a non-eutrophicated zone (site 1), where a macrophyte community (Zostera noltii) is present, up to a strongly eutrophicated zone (site 3), in the inner and shallower areas of the estuary, where the macrophytes disappeared while Enteromorpha spp. blooms have been observed during the last 15 years. This is probably a result of excessive nutrient release into the estuary, coupled with longer persistence of nutrients (nitrogen and phosphorous) in the water column (Marques et al. 1997. Pardal et al. 2000) and the silting up of upstream area. Nevertheless, such macroalgae blooms may not occur in exceptionally rainy years (e.g. year 1994) due to low salinity for long periods, as a result of the Pranto river discharge (Pardal 1998, Pardal et al. 2000, Lillebø et al. 1999, Martins et al. 2001). As general pattern Enteromorpha spp. biomass normally increases from late winter up to July, when an algae crash usually occurs due to anoxia and most of the biomass is washed out to the Atiantic.

Simultaneously, attending to the relationships between extemal abiotic variables and macroalgae growth in this system, temperature, salinity, dissolved oxygen, $\mathrm{pH}$, and dissolved nutrients. like orthophosphate, nitrites, nitrates and ammonium were measured (Fig. 3).
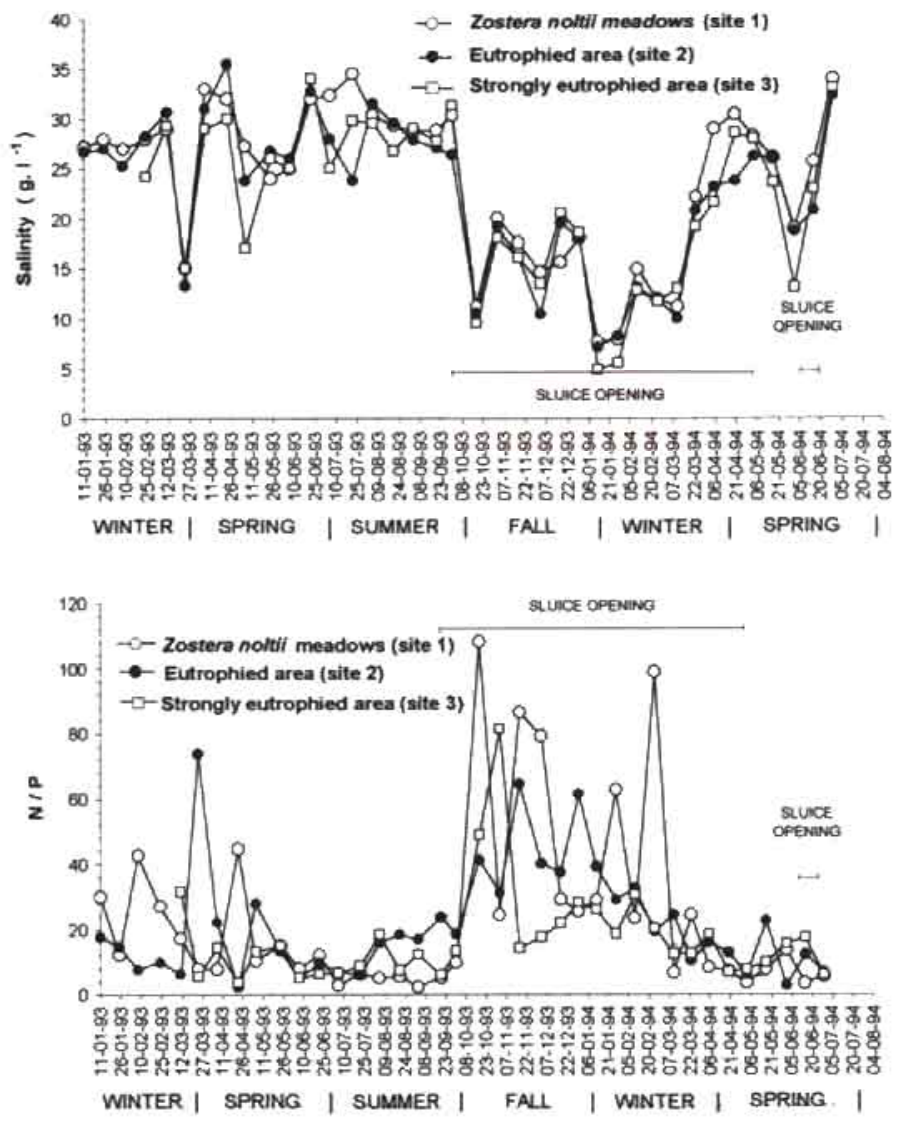

Figure 3. Sampling data (Salinity and N:P ratio) 
Nowadays a sampling program is being done, at stations LT, EA and RP, in order to a better understanding of south arm hydrodynamic behaviour, namely the smooth sinusoidal variation over the tidal cycle of the tide-induced velocities due to coastal zone and estuary geometry.

Sampling data analysis

The data was analysed and discussed in early works (Pardal 1998, Martins et al. 2001 ) in order to understand how the main biochemical variables can be affected by estuarine hydrodynamics. Based on the present knowledge important conclusions were established:

- Fresh water input is controlled by precipitation and sluice management practice (related with the upstream water deficit of rice fields, that can determinate to keep the gates closed even if it is raining). Sometimes there is a time lag between the occurrence of precipitation and sluice gates opening, or the sluice gates remain open for a longer period even without precipitation;

- There is a direct relationship between maximal current velocities and tidal amplitude, being higher when sluice gates are opened. Additionally, turbidity will be higher due to sediments re-suspension increasing;

- Salinity is negatively correlated with freshwater discharges, remaining high (>20 psu) for low river flow values, but it may reach extremely low values (< I psu), such as in January 2001):

- Enteromorpha spp. represent more than $85 \%$ of the total green macroalgae biomass and present important inter-annual variations. Its production depends on the amount of freshwater input in system during late winter and spring. Enteromorpha spp. growth increases with salinity, being the optimum range 17 . 22 psu. (Martins et al. 1999);

- Nitrites and nitrates concentrations, higher in autumn and winter, are strongly correlated with River Pranto freshwater discharge and are not always directly related with precipitation. Ammonium is the major contributor to total inorganic nitrogen;

- The highest orthophosphate concentration occurs mostly in summer, because the increase on efflux of phosphorus from sediments to water column is related with the temperature;

- Macroalgae nutrient uptake rates depend on the difference between internal nutrient concentration and external nutrient concentration in the water. So, primary production can not always be $\mathrm{P}$-limited as suggested by the occurrence of high N:P ratios in the water column;

- Despite of Enteromorpha spp. fixing ability, strong current velocities erode its attachment or tear away their fronds once they reach a critical length (Lowthion et al. 1985).

The dependency of opportunistic macroalgae blooms on precipitation and on river management practices was suggested the usefulness of mathematical modelling application to characterise estuarine hydrodynamics and to estimate residence times, 
related with nutrients and macroalgae exportation or remaining periods in this ecosystem.

Tidal prism

Tidal movement is one of the major driving forces of estuarine circulation in this system and it is also visible in several variables like salinity, turbidity, re-suspension/ deposition of the sediment and transport of pelagic organisms. Tide effects are almost exclusively due to $M 2$ tidal cycle with a full tidal period covering about 12.4 hours. For modelling purposes, the tide characteristics considered are summansed in Table I.

Based on the south arm bathymetry, tidal prism estimation was performed for several tidal ranges, according to Table 1. Results are presented in Table 2 (Duarte 1997).

Flow distribution in an estuary over a tidal cycle shows that the flood current velocities slowly decrease during flood tide and that after slack the ebb flow velocities increase in the opposite direction. Contrarily, after ebb slack the flood tide velocities increase rapidly and the incoming flood tide reaches high flow velocities very quickly.

Table I.Tidal average levels (m) at Figueira da Foz harbour (June 1993-June 1994)

\begin{tabular}{|c|c|c|}
\hline \multicolumn{2}{|c|}{ Maximum level } & 3.7 \\
\hline \multicolumn{2}{|c|}{ Mean level } & 2.0 \\
\hline \multicolumn{2}{|c|}{ Minimum level } & 0.3 \\
\hline \multirow{2}{*}{ Spring tide } & Flood tide & 3.5 \\
\cline { 2 - 3 } & Ebb tide & 0.3 \\
\hline \multirow{2}{*}{ Neap tide } & Flood tide & 2.7 \\
\cline { 2 - 3 } & Ebb tide & 1.8 \\
\hline \multirow{2}{*}{ Selected tide } & Flood tide & 3.3 \\
\cline { 2 - 3 } & Ebb tide & 0.7 \\
\hline
\end{tabular}

Table 2. Tidal prism $\left(\mathrm{m}^{3}\right)$ of south arm Mondego

\begin{tabular}{|c|c|c|c|c|c|c|}
\hline Ebb tide & \multirow{2}{*}{0.0} & \multirow{2}{*}{0.5} & \multirow{2}{*}{1.0} & \multirow{2}{*}{1.5} & \multirow{2}{*}{20} & \multirow{2}{*}{2.5} \\
\hline Flodd tide & & & & & & \\
\hline 2.0 & 960,495 & 890,985 & 723.055 & & & \\
\hline 2.5 & 1.615 .075 & 1.545 .565 & 1.377 .635 & 1.099 .195 & & \\
\hline 3.0 & $2,414,600$ & $2,345,090$ & 2.177 .160 & $1.898,720$ & $1,454,105$ & \\
\hline 3.5 & $3,262,790$ & $3,193,280$ & $3.025,350$ & $2,746,910$ & $2,302,295$ & $1.647,715$ \\
\hline 4.0 & & $4,067,405$ & $3.899,475$ & $3,621.035$ & $3,176,420$ & 2.521 .840 \\
\hline
\end{tabular}


Figure 4 presents smooth sinusoidal variation based on sampling data at LT and RP sites for two (spring and neap) tidal amplitudes.

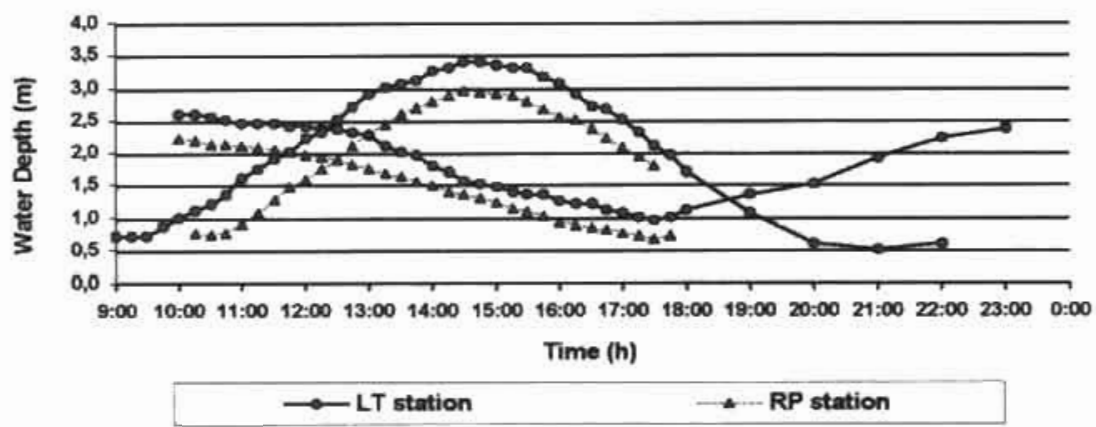

Figure 4.Water level variation over a sponng tide and a neap tide

Model description

\section{DUFLOW Model (1 D)}

The DUFLOW model was designed to cover a large range of applications, such as propagation of tidal waves in estuaries, flood waves in rivers, operation of irrigation and drainage systems and water quality problems. As the relationship between quality and flow gets special attention nowadays and this package is suitable for modelling both, it becomes a useful tool in water quality management.

The package is based on the one-dimensional partial differential equations that describe non-stationary flow in open channels, which are the mathematical translation of the laws of conservation of mass and of momentum. These equations are discretized in space and time using the four point implicit Preissmann scheme. This scheme is unconditionally stable, shows little numerical dispersion and allows non-equidistant grids. It computes discharges and elevations at the same point.

The quality part of the DUFLOW package is based upon the one-dimensional transport equation. This partial differential equation describes the concentration of a constituent in a one-dimensional system as function of time and place. The production term of the equation includes all physical, chemical and biological processes to which a specific constituent is subject to. The user can supply the process descriptions.

$$
\frac{\partial(\mathrm{AC})}{\partial t}=-\frac{\partial(\mathrm{QC})}{\partial x}+\frac{\partial}{\partial x}\left(\mathrm{AD} \frac{\partial \mathrm{C}}{\partial x}\right)+\mathrm{P}
$$

Where:

C Constituent concentration [ $\mathrm{L} \cdot \mathrm{M} \mathrm{M}]$;

Q Flow [L'T'1];

A Cross-sectional flow area [ [ $\left.\mathrm{L}^{\top} \mathrm{T}^{\prime}\right]$; 
D Longitudinal dispersion coefficient $\left[\mathrm{L}^{2} \mathrm{~T}^{-1}\right]$ :

$t$ Time [1];

P Production of the constituent per unit length of the section [ $\left.L^{\prime} \cdot M T^{\prime}\right]$.

This package was applied to south arm Mondego estuary, as a first approach, to estimate the annual nutrient balance. based on current velocities obtained from model results, after model calibration with field data.

Figure 5 presents the increase (always about $60 \%$ ) on average flow velocity due the Gala bridge pillars contracting effect, comparing several sampling values of flow velocity with the model results obtained immediately upstream Gala bridge section (Duarte 1997). The downstream boundary condition used by hydrodynamic model was the water level recorded at this point.
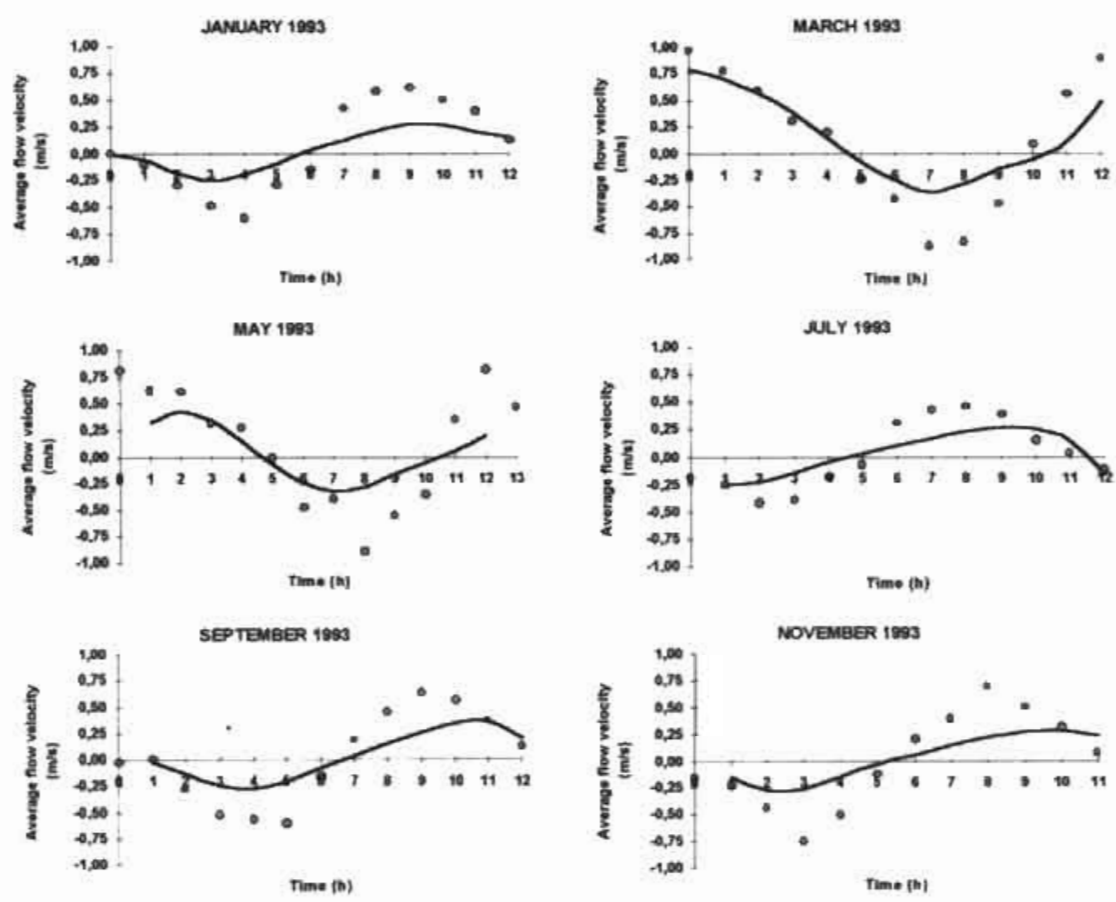

- - Measured data

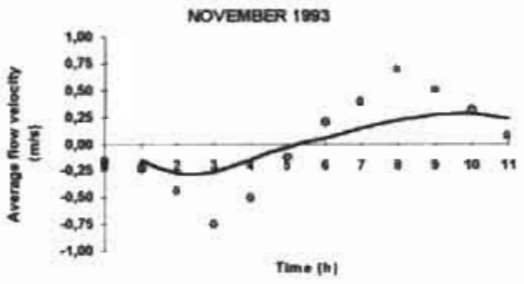

- Duflow model results

Figure 5 Average flow velocity at Gala bridge: pillars effect

\section{SMS Moder (2D.H)}

SMS package was designed as a comprehensive hydrodynamic modelling system being a pre- and post-processor for two-dimensional finite element and finite difference models. Interfaces have designed to be used with the programs RMA2 and RMA4 (US WES-HL, 1996). 
The hydrodynamic model RMA2 is used to compute water surface elevations and flow velocities for shallow water flow problems. This program solves the depth-integrated equations of fluid mass and momentum conservation in two horizontal directions by the finite element method using the Galerkin Method of weighted residuals.

The elements may be one-dimensional lines or two-dimensional quadrilaterals or triangles, even with parabolic sides (Pinho et al. 1999). The shape functions are quadratic for velocity and linear for depth, Integration in space is performed by Gaussian integration and derivatives in time are replaced by a non-linear finite difference approximation. It is not applicable to supercritical flow problems.

The quality model RMA4 is an interface used to assess the migration and dissipation of a constituent, describing its concentration in two horizontal directions as a function of time and place. It uses the hydrodynamic solution from RMAZ to define a flow velocity field for a given mesh and also reads a set of user-specified point loads as input. It was applied with success for longitudinal dispersion coefficient estimation in a Mondego river water quality study (Duarte et al. 1999).

\section{Residence times estimation}

Residence times (RT) are broadly recognised as important descriptors of estuarine behaviour, but no real consensus exists on its definition. Traditionally, a single value has been used to RT evaluation in estuaries to characterise the whole system (Officer \& Kester 1991). This procedure, assuming steady state and well-mixed conditions is attractive to establish comparisons among systems and to estimate ecological quantities. Local analysis is necessary to address important ecological local problems or resulting from local physical processes (e.g. turbidity maximum). Time variability of the environmental forcing also makes RT strongly dependent on the release time (Oliveira and Baptista 1997).

In this work, a sensitivity analysis on RT spatial variability was performed. The effect of various factors (river flow discharge, release time, discharge tracer duration, and tracer mass) was anticipated for invariable tidal conditions. For each point of the physical system. RT was considered as the time period in which the conservative and once-through tracer concentration remains higher than its initial concentration in the system. This concept can be considered as a simplified approach methodology provided that baroclinic and wind forcing were not accounted for, as well as river Pranto flow and tidal cycle time variability were also neglected. Re-entrant and non-conservative tracer behaviour and the effect of other factors like injection point location and river Pranto sluice opening regime will be considered in further research work.

\section{Results and conclusions}

The estuary hydrodynamic model based on RMA2 program was implemented to compute water levels and mean velocity fields, resulting from the tidal and the river Pranto flow forcing. This system, with a total area of about $1.89 \mathrm{~km}^{2}$, was discretized using a 2D mesh (Fig. 6) composed by 3,371 triangular finite elements with 7,020 nodes. Two open boundary conditions were considered: the water surface elevation, defined according the 


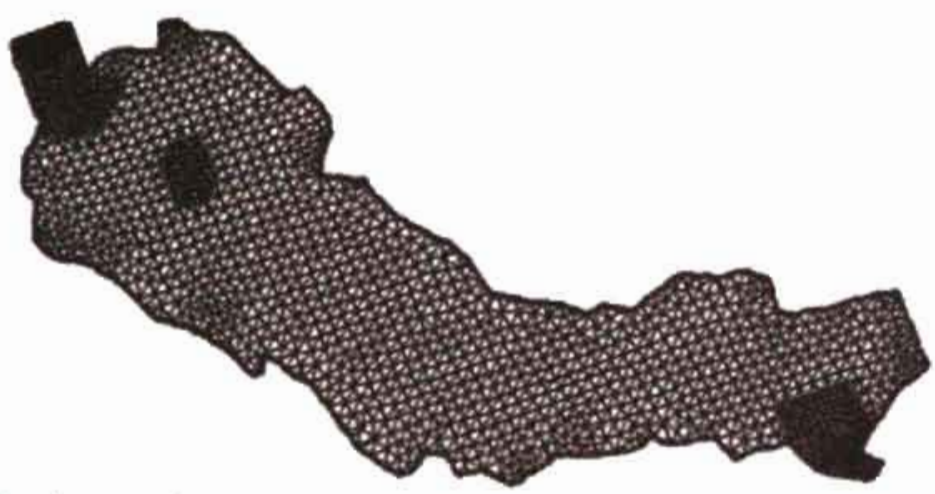

Figure 6. Finite element mesh

characteristics of a semi-diumal M2 selected tide, imposed downstream Gala bridge and a constant flow boundary condition upstream at the river Pranto entrance.

An important intermediate hydrodynamic result is the pattern and the magnitude of estuarine velocity currents. Indeed, for estimation of the potential drift of the opportunistic macroalgae a simultaneous experimental study is being carried out in order to relate the mean current velocities with the critical bottom stresses for
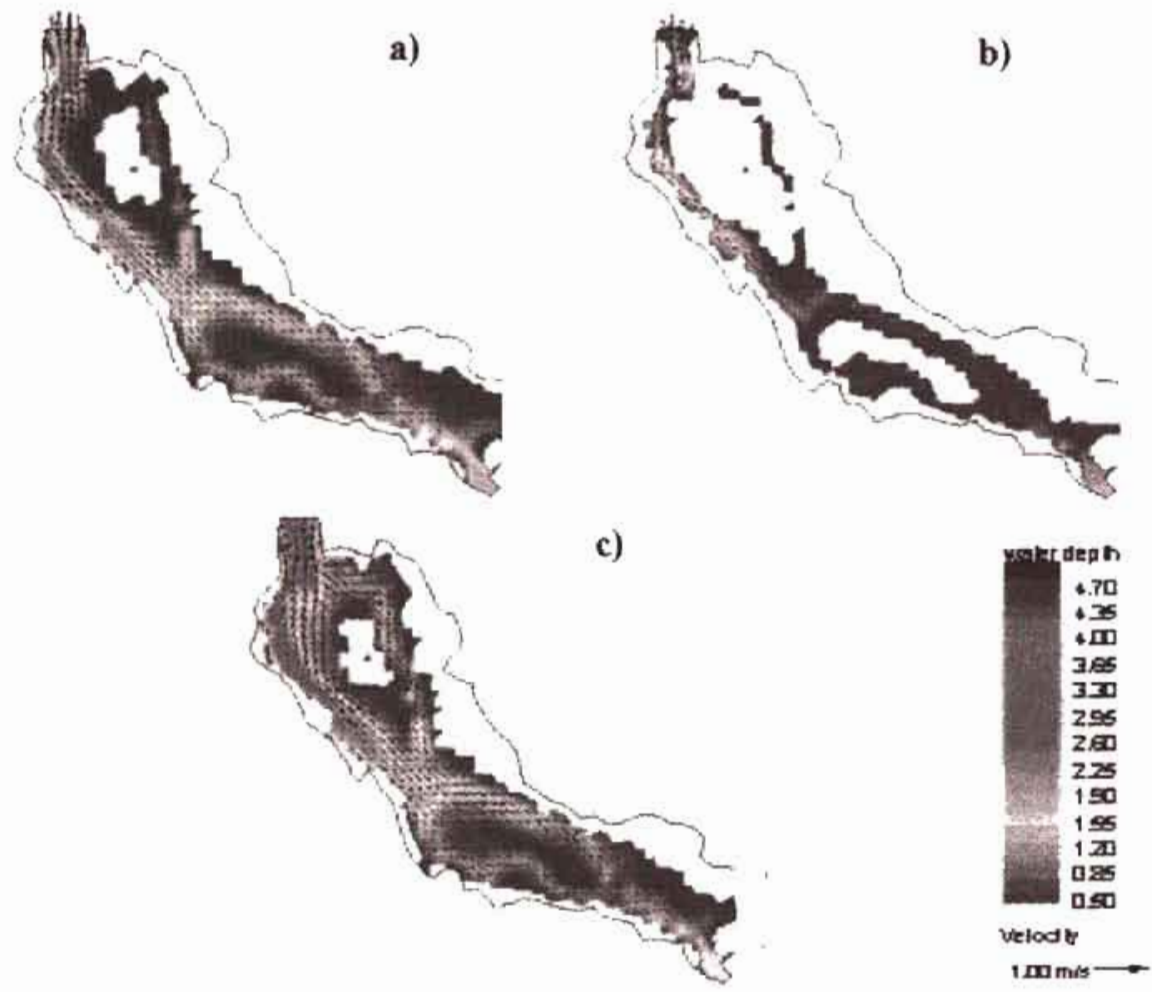

Figure 7. Water depths and velocity fields: a) half, b) three-quarter: c) tidal period 
Enteromorpho drifting. Figure 7 presents the simulated results of water depth and velocity field for the three most representative instants during tidal cycle.

Calibration procedure was performed comparing measured values of velocity and salinity in a few stations with simulated model results. Calibration will be improved when more field data became available.

The simulated scenarios worked out are summarised in Table 3. River Pranto flow variation, mass of tracer injected, time release and tracer discharge were considered in order to assess their effects on spatial estuary residence times variability.

Table 3. Simulated scenarios

\begin{tabular}{|c|c|c|c|c|c|c|c|c|}
\hline \multirow{3}{*}{$\begin{array}{c}\text { River Pranto flow [m/s] } \\
\text { Tracer mass [kg]: } \\
\text { Release Time (h) }\end{array}$} & \multicolumn{4}{|c|}{5} & \multicolumn{4}{|c|}{10} \\
\hline & \multicolumn{4}{|c|}{1,800} & \multicolumn{4}{|c|}{3.600} \\
\hline & 6 & 9 & 6 & 9 & 6 & 9 & 6 & 9 \\
\hline \multicolumn{9}{|l|}{$\overline{T r a c e r}$ discharge duration (h) } \\
\hline 1 & SI & 52 & 56 & $\$ 7$ & $S 11$ & 512 & 516 & 517 \\
\hline 3 & 53 & $\$ 4$ & 58 & 59 & 513 & 514 & 518 & 519 \\
\hline 6 & S5 & $\ldots$ & 510 & - & 515 & + & 520 & - \\
\hline
\end{tabular}

RT obtained from the different simulated scenarios allow to establish the most sensitive zones to estuarine eutrophication process, assuming that nutrients enrichment can be simulated by the tracer presence in most vulnerability zones of the system. Samples of the obtained results for different effects of simulated factors, considering the river Pranto flow value of $5 \mathrm{~m} / \mathrm{s}$, are depicted in Figure 8 .
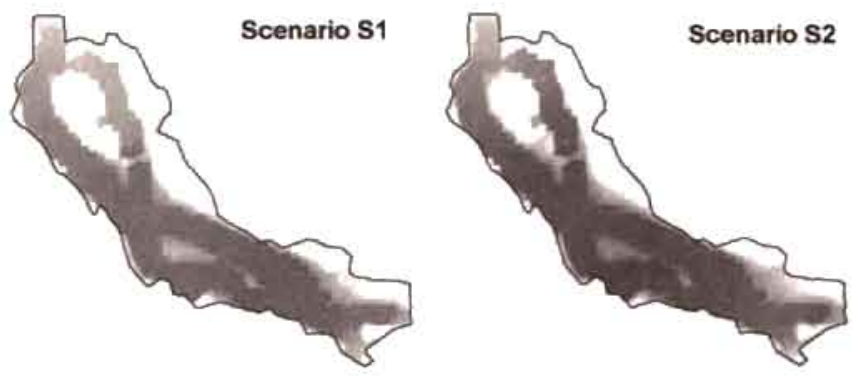

40
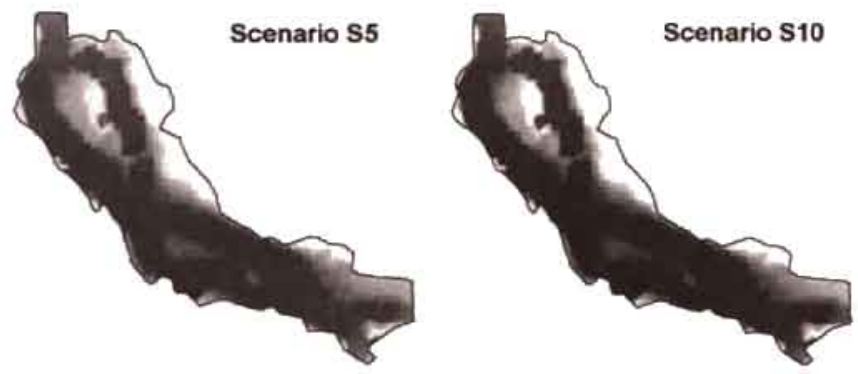

Figure 8. Residence times spatial variation 
The effect of tracer discharge duration can be seen comparing scenarios SI-S5. Scenarios S1-S2 illustrate time-release effect during ebb tide. Tracer mass variation discharge effect can be analysed by means of scenarios S5-SIO. In these conditions, discharges tracer duration appears to be a key parameter for residence time variation. So, when necessary, it is preferable to do more sluice openings, but during a short period of time.

Being a particularity of each ecosystem, the identification of which variables control macroalgal abundance and regulate their biomass, and mostly the quantification of their influence contribute to a deeper knowledge of estuarine eutrophication. helping to find suitable solutions for this environmental problem.

Although these results can be taken as a first approximation, they represent an important step for time scale definition of eutrophication processes in estuarine systems. Modelling results confirm the eutrophication gradient measured in the south arm of the river Mondego estuary, validating the methodology applied.

Since river Pranto is artificially controlled by sluices, the results obtained in this work and its future developments will constitute an important input for optimised operation policy of those hydraulic structures, in order to reduce the negative impact of nutrients discharges from this river in estuarine system.

\section{References}

Berner. E.K and Berner. RA. 1996. Global Envronment Water, Aur and Geochem. Cydes. Prentice-Hall.

Duarte, AALS. (1997). Modelos de Qualidade da Água em Estuários, PAPCC Synthesis work, University of Minho, Portugal. (in portuguese)

Duarte. AALS. Pinho, JLS. Vieira, J.M.P and Boaverrtura. RA.R 1999. Comparison of Numerical Techiniques Solving Longitudinal Dispersion Problerns in the River Mondego. EPMESCM: Computational Methods in Engineering and Science, ed. Bento. J. et al.. Elsever Science, Ltd. Oxford, UK, Vol. 2: $1197-1206$,

Duarte.AALS. Pinho, J.LS. Pardal, M.A. Neto, J.M_Vieira. J.M.P. and Santos, F.S. 2001. Effect of Residence Times on River Mondego Estuary Eutrophication Vulnerability. Water Sci. Technol. 44 (2-3):329-396.

Findt. M.R. Pardal, MA. Lillebø. Al. Martins, I, and Marques, J.C. 1999. Nutnent Cycling and Plant Dynamics in Estuaries: a Brief Review. Acta Oecol. 20: 237-248.

Lavery. PS. and McComb, Af. 1991. Macroalgal-sediment Nutrient Interactions and their Importance to Macroalgal Nutrients in a Eutrophic Estuary Estuar, Coast. Shelf So. 32: 281-295

Lillebø. Al., Pardal, M.A and Marques, J.C. 1999. Population Structure, Dynamics and Production of Hydrobia Ulvoe (Pennant) (Mollusca: Prosobranchia) along an Eutrophication Gradient in the Mondego Estuary (Portugal). Acta Oecol, 20: 289-304.

Lillebo, A.l. 2000. The Effect of Salt Marshes Plants on the Nutrient Dynamics in the Mondego Estuary (Portugal). PhD. Thesis, University of Coimbra, Portugal.

Lowthion, D. Soulsby, R.G. and Houston. M.C.M. 1985. Investigation of an eutrophic tidal basin: Part I - Factors affecting the distribution and biomass of macroalgae. Marine Environment Res. 15:263.284.

Marques, J.C., Pardal, MA. Nilsen, S.N. and jergensen, S.E. 1997. Analysis of the Properties of Exergy and Bıodiversity along an Estuarine of Eutrophication. Ecol. Model. 62. 155-167.

Martins. L., Oliveira. J.M. Flindt. M.R and Marques, J.C. 1999. The Effect of Salinity on the Growth of the Enteromorpha intestinalis (Clorophyta) in the Mondego Estuary Acta Oecol. 20(4): 259-265.

Martins. U.C. 2000. Green Macroalgae and Seagrasses in a Shallow Eutrophic Estuary, the Mondego Estuary. Dynarnics, Controlling Factors and Possible Evolutionary Scenarios. PhD. Thesis, FCT-University of Coimbra, Portugal. 
Martins. I.. Pardal, MA. Lillebø. Al. Flindt. M.R and Marques. J.C. 2001. Hydrodynamics as a Major Factor Controlling the Occurrence of Green Macroalgal Blooms in a Eutrophic Estuary a Case Study on the Influence of Precipration and River Management. Estuar. Coast. Shelf Sci. 52: 165-177.

Officer. C.B and Kester, D.R 1991. On Estimating the non-Advective Tidal Exchanges and Advective Gravitational Circulatoon Exchanges in an Estuary. Estuar. Coast. Shelf Sci. 32: 99-103.

Oiveira. A and Baptusta, A.M. 1997 Diagnostic Modeling of Residence Times in Estuaries. Water Resour. Res. 33: $1935-1946$.

Pardal, MA 1998. Impacto da Eutrofização nas Comunidades Macrobentónicas do Braço Sul do Estuário do Mondego (Portugal). PhD. Thesis, University of Coimbra. Portugal.

Pardal, MA. Marques. J.C. Metelo, I.. Lillebe.A.1, and Findt. MR 2000. Impact of Eutrophication on the Life Cycle, Population Dymamics and Productuon of Ampithoe Volido (Amphipoda) along an Estuarine Spatial Gradient (Mondego Estuary, Portugal). Mar, Ecol, Prog, Ser, 196: 207-219.

Pinho, J.LS. Duarte, AA.LS, Viera, J.M.P. and Carmo, J.SA. 1999. Mesh Generation and Refinement in 2D Hydrodynamic Modelling. A Case Study. EPMESCVIl: Computational Methods in Engineering and Science. ed. Bento, l. et al. Elsever Science, L.td., Oxford, UK, Vol. 2, 1167.1176.

Sfrnso, A. Pavoni, B.Marcomini.A and Orio, A.A. 1992 Macroalgae, Nutrient Cycles and Pollutants in the Lagoon of Venice. Estuaries, 15:518-528.

USWES-HL, 1996. Users Guide to RMA2 Version 4.3, US Army Corps of Engineers - Waterways Experiment Station Hydraulics Laboratory. Vicksburg, USA.

Vieira, JM.P. and Lijkema, L 1989. Development and Application of a Model for Regional Water Quality Managernent Water Res. 23(6): 767-777.

Vieira.JM.P. Pinho. ILS. and Duarte. A.A.LS. 1998. Eutrophication Vulnerability Analysis. a Case Study. Water Sci. Technol. 37(3). $121-128$. 

Série

Investigação

$\bullet$

Coimbra

Imprensa da Universidade

2002 